\title{
Experimental and numerical analysis of short sisal fiber-cement composites produced with recycled matrix
}

\begin{abstract}
The proper use of renewable or recycled source materials can contribute significantly to reducing the environmental impact of construction industry. In this work, cement based composites reinforced with natural fibers were developed and their mechanical behavior was characterized. To ensure the composite sustainability and durability, the ordinary Portland cement matrix was modified by adding metakaolin and the natural aggregate was substituted by $10 \%$ and $20 \%$ of recycled concrete aggregate. Compression and splitting tensile tests indicated that mechanical strength did not seem to be affected by recycled content. Flat sheets were cast in a self-compacted cement matrix and bending tests were performed to determine the first crack, postpeak strength and cracking behavior of the composites. The use of short sisal fiber as reinforcement of recycled cement matrices results in a composite with multiple cracking and increment of strength after first crack. The modeling of composites using finite element method allowed to determine the tensile stress-strain behavior of material and to design possible applications of this new sustainable material.
\end{abstract}

Keywords: natural fiber; recycled concrete aggregate; cement based composite; finite element method

\section{Introduction}

Plant fibers were used during the 1980s for the production of fiber cement as an alternative to metallic roofing tiles, mainly in developing countries of Africa and Asia that were in need of a cheaper material for roofing, which would use less imported resources and could be produced locally (Gram, 1988). Large span tiles (CEPED, 1982) and formwork slabs (Schafer \& Brunssen, 1990) were also produced, further demonstrating the possibility of producing semi-structural constructive elements reinforced with sisal fibers. These constructive elements still had the advantage of using biodegradable fibers, derived from renewable sources and low power consumption for production, which characterizes it as a sustainable building material (Norton \& Sakets, 2000).

However, durability problems resulted in lower mechanical strength of fibrocement with vegetable fibers after a few months, as a result of chemical attack of the sisal fiber by the cement matrix and also the dimensional variation of the fiber due to variations in humidity. This caused the discontinuity of its use until studies on the production of durable cementitious matrices indicated that the use of pozzolanic mineral additions (Toledo Filho, Ghavami \& England, 2003) allows for the maintenance of strength and toughness of the material, even after accelerated aging.

A new interest in the use of vegetable fibers was found, both for production of conventional (Roma, Martello \& Savastano, 2008; Asprone, Durante, Prota \& Manfredi, 2011; Elsaid, Dawood, Seracino, \& Bobko, 2011) and high-performance cementitious composites (Lima, 2004; Melo Filho, Silva \& Toledo Filho, 2013), which showed multiple cracking under bending, demonstrating the potential use of the fiber in the production of building elements with structural or semi-structural capability. However, because of the low fiber-matrix adherence, the latter composites were produced with $6 \%$ of long fibers $(400 \mathrm{~mm})$ and with the use of pressure molding or wollastonite microfibers implying higher production costs and limiting the type of building element. 
The wider applicability of cementitious composites, however, is obtained by using short fibers randomly dispersed in the matrix due to the ease of the mixing and molding process. In conventional matrix, however, multiple cracking behavior cannot be achieved for these sisal-cement composites due to the difficulty in dispersing fiber volume fractions greater than 3-4\% with fiber length higher than 25-30 mm (Hussin \& Zakaria, 1990). In order to produce a composite reinforced with short vegetable fibers that present deflection hardening, a modification of the cement matrix and fiber treatment was developed in the present study, based in previous works (Ferreira, Lima, Silva \& Toledo Filho, 2014). Pozzolanic additions and recycled sand with controlled granulometry were used to ensure durability and fluidity of the mixture. The reduction of the hydrophilicity of the fiber can be obtained by treatment with wetting-drying cycles (Claramunt, Ardanuy \& Garcia-hortal, 2010) and as a result there is a reduction in dimensional change and an increase in fiber-matrix adherence tension (Ferreira, Lima, Silva \& Toledo Filho, 2012).

The use of fine recycled aggregates in matrices for composites reinforced with natural fibers provides greater sustainability to the material, moreover, being a aggregate produced artificially, it is easier to achieve particle size suitable for the development of cement based materials of self-compacting nature. The addition of recycled aggregate in fibrocement also is important to increase the demand for this kind of material, since one of the objectives of Directive 2008/98/EC (European Union, 2008 ) is to increase recycling of non-hazardous construction and demolition waste to at least $70 \%$ by the year 2020. However, the recycled fine aggregate is composed of natural aggregate (NA) bonded with cement mortar, which increases the porosity with respect to NA. When using a classic recycling process, exhibiting only one crushing action by a jaw or impact crusher, approximately $50 \mathrm{wt} \%$ of recycled sand extremely high in filler $(<63 \mu \mathrm{m})$ is obtained (Schoon, Buysser, Driessche \& Belie, 2015) which increases the water absorption capacity with respect to NA. These property is detrimental to fresh state consistency and workability of recycled concrete and mortar and also affecting the mechanical strength and shrinkage of the hardened state (Martínez, Etxeberria, Pavón \& Díaz, 2013; Evangelista \& Brito, 2007; Lima \& Leite, 2012). As a result, most international regulations limit the use of RFA in concrete (Gonçalves \& Brito, 2008). In fact, while the use of large contents of recycled fine aggregate reduces the mechanical strength of mortar (Zhao, Remond, Damidot \& Xu, 2015), up to $30 \%$ RFA to the mixture it is possible provided enough workability and an increase of compressive strength (Bektas, Wang \& Ceylan, 2009, Cuenca-Moyano et al, 2014; Braga, Brito \& Veiga et al, 2012).

The addition of fibers in recycled matrices, in turn, can result in a reduction in the shrinkage of recycled mortar (Mesbah \& Buyle-Bodin, 1999), and assures higher postcracking tensile strength and toughness of concrete with recycled coarse aggregate (Carneiro, Lima, Leite \& Toledo Filho, 2014). By adding steel fiber to recycled aggregate, a new structurally sound material that offers significant benefits in terms of sustainability and cost can be obtained (Senaratne et al, 2016). The effect of polypropylene fiber on properties of concretes using recycled coarse aggregates was investigated by Akça, Çakır \& Ipek (2015); it was found that the mechanical strength decreases with RCA replacement but there is no significant influence observed on the compressive strength of recycled concrete arisen by polypropylene fibers. The results of the study developed by Katzer \& Domski (2013) using steel and polymeric fiber reinforced cement composites (FRCC), created on the basis of waste ceramic aggregate, indicate that there is a future potential of the recycled material for the production of nonstructural and secondary structural FRCC elements. 
Few studies have been conducted about the use natural fibers as reinforcement of recycled cement matrix. A study developed by Carneiro, Lima \& Leite (2010) on the use of recycled filler (size particles $<150 \mu \mathrm{m}$ ) obtained by grinding construction and demolition waste has ensured the development of self-compacting mortar reinforced with coconut fibers. The physical and mechanical properties of fiber cement tiles produced with this material were similar to the properties of ceramic tiles commercially available.

The main objective of this study is to evaluate the influence of recycled fine aggregate (RA) addition on the mechanical properties of natural fiber reinforced cement based composites. The effect of the $10 \%$ and $20 \%$ RA substitution was evaluated in composites reinforced with $4 \%$ of treated sisal fibers $(\mathrm{Lf}=40 \mathrm{~mm})$ for compressive strength, splitting strength and flexural behavior. Numerical analysis was carried out to indentify the post cracking behavior of recycled composite and to simulate the flexural behavior of a fiber cement tile incorporating the experimental data obtained and subjected to usual working load. For that, the version 4.0 of FEMIX computer program, whose purpose is the analysis of structures by the Finite Element Method (FEM), was used.

\section{Material}

Sisal fibers were collected in Valente, state of Bahia - Brazil. Initially, the fibers were washed in hot water $\left(50{ }^{\circ} \mathrm{C}\right)$ to remove surface residues, such as mucilages from the extraction process, and cut to the length of $40 \mathrm{~mm}$. Fiber treatment, conducted according to (Ferreira, Lima, Silva \& Toledo Filho, 2014), consisted in immersing the fibers in water $\left(\mathrm{T} \sim 23{ }^{\circ} \mathrm{C}\right)$ and their removal after saturation $(3 \mathrm{~h})$ for drying in a furnace at a temperature of $80^{\circ} \mathrm{C}(16$ hours $)$. This procedure was repeated 10 times. The tensile tests were performed in a TA.XT Plus Texture Analyzer with a load cell of 500 $\mathrm{N}$ using a displacement rate of $0.03 \mathrm{~mm} / \mathrm{s}$. The tensile strength and elastic modulus was $353 \mathrm{MPa}$ and $15.72 \mathrm{GPa}$, respectively.

Construction and demolition waste (CDW) from a building demolition site in Feira de Santana (Northeast of Brazil) was used to produce the recycled aggregate. The composition of CDW was $56 \%$ of mortar, $27 \%$ of ceramic tiles and bricks, and $17 \%$ of concrete. The concrete phase of waste was crushed separately using a jaw crusher and screened in a sieve of $2.36 \mathrm{~mm}$ to produce the fine recycled concrete aggregate (RA) used in this work. The natural aggregate used was fine sand (NA). To determine the physical properties of the fine aggregates absorption and unit weight tests were carried out as shown in Table 1. The main differences between the recycled aggregate and natural aggregate are their higher finer materials content and higher water absorption ratio. These properties are compatible with the nature of the recycled concrete aggregate and are in accordance with the values observed by Corinaldesi and Moriconi (2009).

[Table 1 near here].

A binder composed of $33 \%$ of Portland composite cement with filler ( $90 \%$ of clinker + calcium sulfate and $10 \%$ of carbonate materials), $27 \%$ of metakaolin and $40 \%$ of fly ash was used. This ratio of fly ash and metakaolin aims to develop a matrix that was free of calcium hydroxide $(\mathrm{CH})$ at 28 days of age to guarantee the durability of the fiber, as shown in the previous research (Lima \& Toledo Filho, 2008; Melo Filho, Silva \& Toledo Filho, 2013). A third generation superplasticizer (Glenium 51) with a solid content of $30.9 \%$ and specific gravity of $1.1 \mathrm{~g} / \mathrm{cm}^{3}$ was used to guarantee a good workability to the mixture. The viscosity modifier Rheomac UW 410 with specific 
gravity of $0.7 \mathrm{~g} / \mathrm{cm}^{3}$, at a dosage of $0.05 \%$ relative to binder, by mass, was also used in order to avoid segregation during molding.

The mixtures were divided into two groups: matrices and cement composites with $4 \%$ of fiber, by mass. Previous work (Ferreira, Lima, Silva \& Toledo Filho, 2014) indicated that it was possible to obtain multiple cracking with cement based composites reinforced with $4 \%$ and $6 \%$ of sisal fibers. In each group three mixtures were produced and the difference between these mixtures is the recycled aggregate replacement percentage, as shown in Table 2 . The aggregates substitution rates, by mass, were $10 \%$ RCA and $20 \%$ RCA. The water/cement ratio was kept constant as 0.45 .

[Table 2 near here].

\section{Test methods}

A compressive test, according to ASTM Standard C39 (ASTM, 2002) and a tensile splitting strength test, according to ASTM Standard C496 (ASTM, 1999) were carried out in three cylindrical specimens of dimensions $100 \mathrm{~mm}$ in diameter and $200 \mathrm{~mm}$ in height, after 28 days of curing in water immersion. The specimens were tested on a $2000 \mathrm{kN}$ Contenco testing machine, with load cells of $1000 \mathrm{kN}$ and $50 \mathrm{kN}$. For compressive test and tensile test axial loads of $1000 \mathrm{~N} / \mathrm{s}$ and $500 \mathrm{~N} / \mathrm{s}$ were used, respectively. For the flexural test, initially flat plates with the dimensions of $400 \mathrm{~mm} \mathrm{x}$ $400 \mathrm{~mm} \times 10 \mathrm{~mm}$ were molded (see Fig.1a). The mortar mix was placed in a steel mould using the manual technique, followed by external vibration. After 28 days, the plates were cut into small plates with the dimensions of $400 \mathrm{~mm} \times 70 \mathrm{~mm} \times 10 \mathrm{~mm}$. A Shimadzu UH-F $1000 \mathrm{kN}$ was used for the determination of the mechanical properties of the composites at 28 days of age. Flexural tests were carried out under displacement control at a crosshead rate of $0.3 \mathrm{~mm} / \mathrm{min}$ (Fig. 1b). Three specimens for each mix were tested under a four-point bending (300 mm span; $100 \mathrm{~mm}$ span between loads). Equivalent stress was obtained by utilization of the following equation:

$\sigma=(\mathrm{P} . \mathrm{L}) /\left(\mathrm{b} . \mathrm{e}^{2}\right)$

where $\mathrm{P}$ is the load, $\mathrm{L}=$ span of plate between supports, $\mathrm{b}=$ width of plate and $\mathrm{e}=$ thickness of plate.

[Figure 1 near here].

The effect of the recycled aggregate on toughness of the sisal fiber reinforced composite was measured using the Toughness Index ( $\left.\mathrm{T}_{\mathrm{n}}\right)$, based NBN B 15238 (IBN, 1992), defined as the energy (area under load-displacement curve) required to deflect the composite plate to a midpoint deflection of $\mathrm{L} / \mathrm{n}$ of its free span. In this study, toughness index $T_{150}$ and $T_{15}$ was obtained to deflections of 2 and $20 \mathrm{~mm}$, respectively.

To investigate the statistical influence of recycled aggregate and fiber content on the mechanical properties of matrix and composite with natural aggregate, the analysis of variance (ANOVA) and Tukey's test evaluated at 5\% significance level were used.

\section{Experimental results and discussion}

The experimental results are shown in Table 3. Fig. 2 shows flexural stressdisplacement curves for the recycled and natural composites. 
The effect of RA content and fiber on compressive strength can be observed in Table 4 that shows the ANOVA results. From this table it is observed that RA alone are not change the compressive strength but the fiber content, and your interaction with RA, are affecting this property.

Studies on the influence of fine recycled aggregates on the mechanical strength of concrete and mortar have shown conflicting results. Among the factors that affect the results are the content and the type of recycled aggregate used, cement/water ratio, moisture content of the aggregate, and even grain shape (Evangelista \& Brito, 2014; Silva, Brito \& Veiga, 2009; Martínez, Etxeberria, Pavón \& Díaz, 2013; Lima \& Leite, 2012). In this work, the results of Tukey's pairwise comparison indicate that the mean values of compressive strength of mixes REF, 10RA and 20RA, shown in Table 3, are statistically equal. A similar result was obtained when the mixes REF4F, 10RA4F and 20RA4F were compared, showing that the recycled aggregate does not affect the compressive strength of composites. According Katz (2003) the maintenance of the compressive strength with increasing fine aggregate replacement can be explained by high levels of cement (both hydrated and non-hydrated) that reach as much as $25 \%$ of its weight, increasing the total amount of cement in the mix.

[Table 3 near here].

[Figure 2 near here].

[Table 4 near here].

Figure 3 indicates the influence of sisal fiber on the mechanical properties of the matrices. A decrease of compressive strength (fc) ranging from 37 to $43 \%$ was observed, but the lowest value obtained, of about $15 \mathrm{MPa}$, is still sufficient for use of this material in structural applications. This decrease of the compressive strength with the increase of content of natural fibers has been observed by others authors (Chatveera \& Nimityongskul, 1992; Paramasivam, Nathan \& Gupta, 1984) due to an increase in the porosity of the matrix with the content of short fiber in the mixture. This effect of fiber on the mechanical properties is influenced by the fiber reinforcement characteristics, such content and fiber length, and the type of used matrix used. For self-compacting matrices, the mechanical damage associated with the addition of fibers is reduced due to better distribution of fiber that results in a more homogeneous material (Lima, Toledo Filho \& Melo Filho, 2014).

The effect of recycled aggregate and fiber content on the splitting strength (fsp) doesn't show statistical difference between the mean values of mixes, considering the results of Tukey's pairwise comparison.

[Figure 3 near here].

For the flexural behavior (see Figure 2), the composites show a deflection hardening response with multiple cracking formation. The flexural behavior begins with an elasticlinear range where both matrix and the fiber behave linearly up to the crack initiation of the matrix. The end of the linear elastic range is delimited by the stress at first crack ( $\sigma_{f c}$ ). Mean values of 2.90, 3.43 and $3.06 \mathrm{MPa}$ for $\sigma_{f c}$ were obtained for to composites with natural aggregate, 10\% RA and 20\% RA composite, respectively (see Table 3). The post cracking range was characterized by a multiple cracking formation until no more cracks can form. The widening of the existing cracks takes place and the crack spacing becomes constant, similar to that observed by Melo Filho, Silva \& Toledo Filho 
(2013). The maximum flexural stress $\left(\sigma_{b}\right)$ observed in this region was higher than first cracking strength for all mixtures, indicating the flexural hardening behavior of the composite. Mean values of $\sigma_{b}$ ranged between 3.33 to 3.53 were observed. Despite a variation in mean values, the statistical analysis evidenced no significant difference between the three mixes for $\sigma_{f c}$ and $\sigma_{b}$.

[Figure 4 near here].

Similar flexural behavior was obtained in a previous work (Ferreira, Lima, Silva \& Toledo Filho, 2014) with short sisal fiber reinforced cement-composites and associated to fiber treatment that resulted in an increase in the fiber-matrix bond. The maximum stress was followed by a strain softening response due to the localization and widening of one of the existing cracks. The reduction of stress occurred after a displacement of around $15 \mathrm{~mm}$ for all composites. The addition of recycled aggregate did not affect the cracking pattern of the composite, showed in Figure 4.

[Figure 4 near here].

The toughness index $T_{\mathrm{n}}$ determined for a deflection of $2 \mathrm{~mm}$ and $20 \mathrm{~mm}$ are presented in Table 3. Figure 5 shows that the addition of RA in matrix led to a reduction in the values of toughness compared to those of specimens with natural aggregate. It is verified a decrease of toughness index $\mathrm{T}_{150}$ of $14 \%$ and $18 \%$ when $10 \%$ and $20 \%$ RA are used, respectively. The same trend can be observed for the $\mathrm{T}_{15}$ which have a decreased of $13 \%$ and $16 \%$ with the same increment of the RA. The values of toughness obtained in flexural test (maximum value of 1667.25 N.mm) demonstrate the high capacity of the short sisal fibers to enhance the ductility of cement based matrix. For the conventional cement based matrices reinforced with 3\% of random and aligned fibers of sisal or coir, for example, Toledo Filho, Ghavami, England \& Scrivener (2003) found maximum values of toughness of 990 N.mm, for a deflection of $2 \mathrm{~mm}$.

[Figure 5 near here].

\section{Numerical modeling}

The main objective of the present section is the assessment of the potentialities of sisal fibre reinforced cement composite (SisFRCC) for the development of new constructive elements of semi-structural character. Taking advantage of the capabilities of existing advanced computer programs for the material nonlinear analysis of cement based structures, this aim will be explored by selecting a software that integrates constitutive models prepared for the simulation of the nonlinear behaviour of fibre reinforced cement composites (Barros, Pereira, Gouveia \& Azevedo, 2007). Version 4.0 of the FEMIX computer program was used. FEMIX 4.0 is a computer code whose purpose is the analysis of structures by the Finite Element Method (FEM). In the context of finite element material nonlinear analysis of concrete shell structures, the adopted crack constitutive model was implemented under the framework of the ReissnerMindlin theory adapted to the case of layered shells.

\subsection{Assessment of the parameters of the constitutive model.}

The values of parameters of the constitutive model were determined by fitting, as much as possible, the force-deflection relationship obtained in the experimental tests, as 
shown in Figure 6. For modeling the half length of the SisFRCC specimens in these tests (taking advantage of the structural symmetry), a mesh of 20x10 eight node Reissner-Mindlin shell finite elements with $2 \times 2$ IP was adopted. Each element was decomposed in ten layers of equal thickness. Due to the relatively high fracture mode I energy of the SisFRCC, a softening diagram was adopted for both the in-plane and outof-plane shear components, by considering the values presented in Table 5. The details of the model are described elsewhere (Gouveia, 2011).

[Figure 6 near here]

[Table 5 near here]

The tensile stress crack-width obtained from this inverse analysis that simulates the post-cracking behavior of this composite SisFRCC is represented in Fig. 7a, where the crack width was obtained by multiplying the strain normal to the crack, $\varepsilon_{n}^{c r}$, with the crack bandwidth, $l_{b}$, according to the diagram of Fig. $7 \mathrm{~b}$. The shape of this diagram, as well as the fracture energy obtained, is consistent with the results obtained by Baluch, Ziraba \& Azad (1987). In cement based matrix, the tensile stress crack-width behavior is characterized by a softening due to the bridging action of aggregates and cement ligaments and can be represented by the bilinear $\sigma-\mathrm{W}$ relationship proposed by the CEB-FIP Model Code (CEB, 1993) presented in Fig 7a with $\alpha_{1}=0.15$. The presence of fiber modified this behavior. After abrupt load decay $\left(\alpha_{1} f_{c t}=0.84 \mathrm{MPa} ; w_{1}=0.04 \mathrm{~mm}\right)$ due to the incapacity of fibers to support the energy release in the fracture of the matrix, a pseudo-hardening phase occurred $\left(\alpha_{2} f_{c t}=1.26 \mathrm{MPa} ; w_{2}=0.4 \mathrm{~mm}\right)$, more pronounced in the SisFRCC developed in the scope of the present research program due to the higher content and longer sisal fibers used. The crack is being bridged by resisting fibers and the fiber pullout mechanism contributes to the energy resistance of the material during propagation of the crack. Finally a softening stage is developed up to a maximum crack width $\left(w_{u}\right)$ of about $4 \mathrm{~mm}$.

[Figure 7 near here].

\subsection{Exploring the potentialities of SisFRC for new construction systems.}

SisFRCC reinforced with $\mathrm{Vf}=4 \%$ of sisal fibers is explored for the development of the constructive element represented in Fig. 8. By executing a preliminary design using DOCROS software (Varma, Barros \& Sena-Cruz, 2012), which is capable of determining the moment-curvature of a cross section of elements failing in bending, and considering the values included in Table 4 for the material nonlinear constitutive model, the geometry proposed in Fig. 8a was determined for a span length of $2.0 \mathrm{~m}$.

[Figure 8 near here].

This folder plate element can be utilized as a roofing structural system. The behavior of this folder plate was studied for the load conditions represented in Fig. 8b: case 1) uniformly distributed load on the bottom component, case 2) uniformly distributed load on the top flanges. These loading conditions aim to estimate the behavior of this element when submitted to extreme severe load conditions that might occur.

This folder plate element was simulated by a finite element mesh composed of eight node Reissner-Mindlin shell elements with $2 \times 2$ IP. The thickness is constant and equal 
to $10 \mathrm{~mm}$, and it was decomposed in 10 layers. The properties of the SisFRCC reinforced with Vf $=4 \%$ of sisal fibers for the FEM simulations are those presented in Table 4.

The relationship between applied load (p), for load case 1, and the mid-span vertical deflection are represented in Fig. 9a. The distributed load attained a first peak value of about $14.3 \mathrm{kN} / \mathrm{m}^{2}$ at a deflection of $1.5 \mathrm{~mm}$. At this deflection the crack pattern is represented in Fig. 9b for the top layers. An abrupt load decay occurred at this deflection level (at about $1.5 \mathrm{~mm}$ of midspan deflection), and the behavior of the element presented a deflection hardening stage due to the relatively high energy absorption capacity of the SisFRCC. At a deflection of L/200 $=10 \mathrm{~mm}$ (which can be considered a deflection limit for serviceability limit conditions for this type of element), the uniformly distributed load is $14.6 \mathrm{kN} / \mathrm{m}^{2}$ and the crack patterns in the bottom and top layers are represented in Fig. 10a and 10b, respectively. At this stage a flexural failure band is formed in the central part of the element, followed by the closing of the neighboring cracks, with shear cracks progressing in the webs of the element close to the supports. This arch effect provided by the webs of the element is also responsible for the ductile response and pseudo-hardening behavior of the element.

[Figure 9 near here].

[Figure 10 near here].

The uniformly distributed load versus vertical deflection in mid span, for load case 2, is represented in Fig. 11a. The structure attained a first peak load of about $4 \mathrm{kN} / \mathrm{m}^{2}$ for a deflection of about $5 \mathrm{~mm}$, with the crack pattern in the top layer represented in Fig. 11b. In the bottom layer only two micro-cracks formed at the support region of the element. After this deflection the structure presented a stage of moderate increase of load capacity up to a deflection of about $90 \mathrm{~mm}$, followed by a stage of structural softening due to an intense opening of the cracks localized in the transition zone between webs and bottom flange.

[Figure 11 near here].

\section{Conclusion}

In this paper, the mechanical behavior of sisal fiber-cement composites is presented. The following conclusions can be drawn based on the results obtained in the present investigation.

(a) The use of recycled fine aggregate does not statistically affect the mechanical properties of the matrix or composites, despite its higher absorption and fines content, compared with natural aggregate.

(b) As expected, the addition of short fiber results in the reduction in the compressive strength. However, compared with literature results of sisal-cement made with conventional matrices, the self compacting matrix used in this work allowed a better homogenization of mix and decrease of damage associated with the addition of fibers.

(c) The use of mineral additions, as partial replacement of Portland cement, and chemical additives resulted in a selfcompating matrix that promoted an adequate casting of mixtures and the production of a composite with multiple cracking behavior under flexural load. 
(d) Numerical simulation of folded plate, using finite element method based program, showed maintenance load after the cracking of the sisal fiber reinforced folder plate until deflection limit for serviceability conditions for this type of elements.

\section{Disclosure statement}

No potential conflict of interest was reported by the authors.

\section{References}

Akça, K. R., Çakır, Ö., \& Ipek, M. (2015). Properties of polypropylene fiber reinforced concrete using recycled aggregates. Construction and Building Materials, 98, 620-630.

Asprone, D., Durante, M., Prota, A., \& Manfredi, G. (2011). Potential of structural pozzolanic matrix-hemp fiber grid composites. Construction and Building Materials, 25(6), 2867-2874.

ASTM C 39/C 39M (2002). Standard test method for compressive strength of cylindrical concrete specimens. Annual Book of ASTM Standards, vol. 04.02, American Society for Testing and Materials, Philadelphia.

ASTM C 496 (1999). Standard method for splitting tensile strength of cylindrical concrete specimens, Annual Book of ASTM Standards, ASTM 4.02.

ASTM C 1018 (1989). Standard test method for flexural toughness and first-crack strength of fiber-reinforced concrete, Designation C1018-89, ASTM Book of Standards, Vol. 04.02.

Baluch, H., Ziraba, Y.N., \& Azad, A.K. (1987). Fracture characteristics of sisal fibre reinforced concrete. The International Journal of Cement Composites and Lightweight Concrete, 3(2), 157-168.

Barros, J.A.O., Pereira, E.N.B., Gouveia, A.V. \& Azevedo, A.F.M. (2007). Numerical simulation of thin steel fiber self-compacting concrete structures. In: ACI SP-248 Deflection and stiffness issues in FRC thin structural elements, Edited by Peter Bischoff and Faris Malhas, paper SP-248-1, pp.1-16.

Bektas, F., Wang, K. \& Ceylan. H. (2009). Effects of crushed clay brick aggregate on mortar durability. Construction and Building Materials, 23(5), 1909-1914.

Braga, M., de Brito, J., \& Veiga, R. (2012). Incorporation of fine concrete aggregates in mortars. Construction and Building Materials, 36, 960-968.

Carneiro, J.A.. Lima, P.R.L., Leite, M.B., \& Toledo Filho, R.D. (2014). Compressive stress-strain behavior of steel fiber reinforced-recycled aggregate concrete, Cement and Concrete Composites, 46, 65-72.

Carneiro, V.L., Lima, P.R.L., \& Leite, M.B. (2010). Evaluation of physical and mechanical properties of self compacting composites pastes reinforced with coir short fibers In: Congresso Ibérico sobre betão auto-compactável, 2010, Guimarães. bac2010 - 2o Congresso Ibérico sobre betão auto-compactável. pp.1-10 (In Portuguese)

CEPED. (1982) Use of plant fibers in fibercement and fiber-concrete. BNH-DEPEA, Rio de Janeiro. (In Portuguese)

Chatveera, B., \& Nimityongskul, P. (1992). Mechanical properties of sisal fiber-mortar composites containing rice husk ash. In: Fibre reinforced cement and concrete, 1992, London. Proceedings of the Fourth RILEM International Symposium. London: RILEM, 1992. p.1056 - 1072 
Claramunt, J., Ardanuy, M., \& Garcia-hortal, J.A. (2010). Effect of drying and rewetting cycles on the structure and physicochemical characteristics of softwood fibres for reinforcement of cementitious composites, Carbohydrate Polymers, 79, 200-205.

COMITE EURO-INTERNATIONAL DU BETON (CEB) \& FEDERATION INTERNATIONALE DE LA PRÉCONTRAINTE (FIP) Model Code 1990 - Design code, Lausanne : Thomas Telford Services Ltd, 1991

Corinaldesi, V., \& Moriconi. G. (2009). Behaviour of cementitious mortars containing different kinds of recycled aggregate. Construction and Building Materials 23:1, 289294.

Cuenca-Moyano, G. M., Martín-Morales, M., Valverde-Palacios, I., Valverde-Espinosa, I., \& Zamorano, M. (2014). Influence of pre-soaked recycled fine aggregate on the properties of masonry mortar. Construction and Building Materials, 70, 71-79.

Elsaid, A., Dawood, M., Seracino, R., \& Bobko, C. (2011). Mechanical properties of kenaf fiber reinforced concrete. Construction and Building Materials, 25(4), 1991-2001.

European Union. (2008). European Union Directive 2008/98/EC of the European Parliament and of the Council of 19 November 2008 on Waste and Repealing Certain Directives. Official Journal of the European Union, 22/11/2008 (2008)

Evangelista, L., \& De Brito, J. (2007). Mechanical behaviour of concrete made with fine recycled concrete aggregates. Cement and Concrete Composites, 29(5), 397-401.

Evangelista, L., \& De Brito, J. (2014). Concrete with fine recycled aggregates: a review. European Journal of Environmental and Civil Engineering, 18(2), 129-172.

Ferreira, S.R., Lima, P.R.L., Silva, F.A., \& Toledo Filho, R.D. (2012). Effect of sisal fiber hornification on the adhesion with portland cement matrices. Matéria (Rio de Janeiro), 17(2), 1024-1034. (in Portuguese).

Ferreira, S. R., Lima, P. R. L., Silva, F. A., \& Toledo Filho, R. D. (2014). Effect of Sisal Fiber Hornification on the Fiber-Matrix Bonding Characteristics and Bending Behavior of Cement Based Composites, Key Engineering Materials, 600, 421-432.

Gram, H.E. (1988) Natural fibre concrete roofing. In: Natural fibre reinforced cement and concrete, Anais... Edited by R.N.Swamy, Blackie and Son Ltd, London, v.5, pp. 257-285

Gonçalves, P., \& Brito, J. (2008). Use of recycled concrete aggregate: commented analysis of existing regulations. Engenharia Civil, 32, 73-86. (in Portuguese).

Gouveia, A. V. (2011). Constitutive models for the material nonlinear analysis of concrete structures including time dependent effects. Guimarães. Tese (Doutorado). Department of Civil Engineering, University of Minho.

Hussin, M.W. \& Zakaria, F. (1990). Prospects For Coconut Fibre- Reinforced Thin Cement Sheet in the Malaysian Construction Industry, Proceedings of the Second International RILEM Symposium,1st edition, Chapman \& Hall, London (ed. H.S Sobral), pp. 77-80.

IBN Norme Belge NBN B 15 238. Essais de béton reforcé de fibres-essai de flexion sur éprouvettes prismatiques. Brussels: Institut Belge de Normalisation (IBN); 1992. p. 9.

Katz, A. (2003). Properties of concrete made with recycled aggregate from partially hydrated old concrete. Cement and concrete Research, 33(5), 703-711. 
Katzer, J., \& Domski, J. (2013). Optimization of fibre reinforcement for waste aggregate cement composite. Construction and Building Materials, 38, 790-795.

Lima P.R.L. (2004). Theoretical analysis and experimental characterization of composites reinforced with sisal fibre. [Thesis]. Rio de Janeiro: Federal University of Rio de Janeiro. (In Portuguese)

Lima, P.R.L., \& Toledo Filho, R.D. (2008). Use of metakaolin to improve the durability of sisal fibercement based composites (in Portuguese). Ambiente Construído, 8(4), 7 19.

Lima, P.R.L., \& Leite, M.B. (2012). Influence of CDW recycled aggregate on drying shrinkage of mortar. Open Journal of Civil Engineering, 2(2), 53-57.

Lima, P.R.L., Toledo Filho, R. D., \& Melo Filho, J. A. (2014). Compressive stressstrain behaviour of cement mortar-composites reinforced with short sisal fibre. Materials Research, 17(1), 38-46.

Martínez, I., Etxeberria, M., Pavon, E., Díaz, N.. (2013). A comparative analysis of the properties of recycled and natural aggregate in masonry mortars. Construction and Building Materials, 49, 384-392.

Melo Filho, J. A, Silva, F. A., \& Toledo Filho, R. D. (2013). Degradation kinetics and aging mechanisms on sisal fiber cement composite systems. Cement and Concrete Composites, 40, 30-39.

Mesbah, H. A., \& Buyle-Bodin, F. (1999). Efficiency of polypropylene and metallic fibres on control of shrinkage and cracking of recycled aggregate mortars. Construction and Building Materials, 13(8), 439-447.

Norton, B., \& Skates, H. (2000). Technologies for sustainable buildings. In: World renewable energy congress VI. Anais... Edited by Elsevier, pp. 142-147.

Paramasivam, P., G. K. Nathan, \& Gupta, N.C. (1984). Coconut fibre reinforced corrugated slabs. International Journal of Cement Composites and Lightweight Concrete, 6 (1), 19-27.

Roma Jr, L.C., Martello, L.S., \& Savastano Jr, H. (2008). Evaluation of mechanical, physical and thermal performance of cement-based tiles reinforced with vegetable fibers. Construction and Building Materials, 22(4), 668-674.

Schafer H.G., \& Brunssen G.W. (1990) Sisal-Fibre Reinforced Lost Form Work for Floor Slabs. In: Second intl. Symp. of RILEM on vegetable plants and their fibres as building materials. Salvador. Proceedings..., London, Edited by Sobral, H.S., Chapman and Hall, pp. 173-181.

Schoon, J., De Buysser, K., Van Driessche, I., \& De Belie, N. (2015). Fines extracted from recycled concrete as alternative raw material for Portland cement clinker production. Cement and Concrete Composites, 58, 70-80.

Senaratne, S., Gerace, D., Mirza, O., Tam, V. W., \& Kang, W. H. (2016). The costs and benefits of combining recycled aggregate with steel fibres as a sustainable, structural material. Journal of Cleaner Production, 112, 2318-2327.

Silva, J., de Brito, J., \& Veiga, R. (2009). Incorporation of fine ceramics in mortars. Construction and Building Materials, 23(1), 556-564. 
Silva, F. D. A., Fairbairn, E. D. M. R., Toledo Filho, R. D., \& Melo Filho, J. D. A. (2010). Physical and mechanical properties of durable sisal fiber-cement composites. Construction and Building Materials, 24(5), 777-785.

Toledo Filho, R.D., Ghavami, K., \& England, G. L. (2003). Development of vegetable fibre-mortar composites of improved durability. Cement and Concrete Composites, $25: 2,185-196$.

Varma, R., Barros, J.A.O., \& Sena-Cruz, J.M. (2012). Design-curves of strain softening and strain hardening fibre reinforced concrete elements subjected to axial load and bending moments. In: 8th RILEM international symposium on fibre reinforced concrete: challenges and opportunities. Guimarães. Proceedings... Eds: Joaquim Barros et al., pp.19-21.

Zhao, Z., Remond, S., Damidot, D., \& Xu, W. (2015). Influence of fine recycled concrete aggregates on the properties of mortars. Construction and Building Materials, 81, 179-186. 
Table 1. Characterization of aggregates

\begin{tabular}{lcc}
\hline \multicolumn{1}{c}{ Characteristic } & Natural aggregate & Recycled aggregate \\
& NA & RA \\
\hline Maximum diameter $(\mathrm{mm})$ & 1.20 & 2.36 \\
Fineness & 1.73 & 2.11 \\
Materials finer than $150 \mu \mathrm{m}(\%)$ & 0.95 & 14.36 \\
Absorption $(\%)$ & 0.03 & 6.11 \\
Unit weight $\left(\mathrm{kg} / \mathrm{dm}^{3}\right)$ & 2.65 & 2.60 \\
\hline
\end{tabular}

Table 2. Mix proportions of natural (REF) and recycled aggregates matrices and composites $\left(\mathrm{kg} / \mathrm{m}^{3}\right)$

\begin{tabular}{ccccccccc}
\hline Mix & Cement & $\begin{array}{c}\text { Fly } \\
\text { Ash }\end{array}$ & Metakaolin $\begin{array}{c}\text { Natural } \\
\text { aggregate }\end{array}$ & $\begin{array}{c}\text { Recycled } \\
\text { aggregate }\end{array}$ & Water & SP & Fiber \\
\hline \multicolumn{7}{c}{ Group 1 - Matrix } \\
\hline REF & 314.52 & 381.24 & 257.34 & 476.55 & - & 428.90 & 24.71 & - \\
10RA & 314.41 & 381.11 & 257.25 & 428.75 & 47.64 & 428.75 & 24.71 & - \\
20RA & 314.31 & 380.98 & 257.16 & 380.98 & 95.24 & 428.60 & 30.86 & - \\
\hline \multicolumn{7}{c}{ Group 2 - Cement composite reinforced with 4\% of fiber } \\
\hline REF4F & 301.74 & 365.75 & 246.88 & 457.18 & - & 411.47 & 59.26 & 36.57 \\
10RA4F & 301.64 & 365.63 & 246.80 & 411.33 & 45.70 & 411.33 & 68.13 & 36.56 \\
20RA4F & 301.54 & 365.51 & 246.72 & 365.51 & 91.38 & 411.19 & 74.02 & 36.55 \\
\hline
\end{tabular}

Table 3. Mechanical results (coefficient of variation in parentheses, in \%)

\begin{tabular}{lccc}
\hline \multirow{2}{*}{ Property } & \multicolumn{3}{c}{ Matrix } \\
\cline { 2 - 4 } & REF & 10RA & 20RA \\
\hline fc $(\mathrm{MPa})$ & $30.42(0.8)$ & $30.24(0.3)$ & $31.27(2.0)$ \\
$\mathrm{fsp}(\mathrm{MPa})$ & $2.13(11.6)$ & $2.09(19.4)$ & $2.06(15.5)$ \\
\hline \multicolumn{3}{c}{ Composite } \\
& REF4F & $10 \mathrm{RA} 4 \mathrm{~F}$ & $20 \mathrm{RA} 4 \mathrm{~F}$ \\
\hline fc $(\mathrm{MPa})$ & $18.66(1.1)$ & $18.91(4.19)$ & $17.86(3.5)$ \\
$\mathrm{fsp}(\mathrm{MPa})$ & $2.23(1.1)$ & $2.22(3.0)$ & $2.21(1.8)$ \\
$\sigma_{\text {fc }}(\mathrm{MPa})$ & $2.90(12.4)$ & $3.43(12.8)$ & $3.06(16.0)$ \\
$\sigma_{\mathrm{b}}(\mathrm{MPa})$ & $3.33(3.8)$ & $3.53(4.4)$ & $3.35(2.6)$ \\
$\mathrm{T}_{150}(\mathrm{~N} . \mathrm{mm})$ & $176.51(21.8)$ & $151.67(22.6)$ & $144.01(1.0)$ \\
$\mathrm{T}_{15}(\mathrm{~N} . \mathrm{mm})$ & $1667.25(8.7)$ & $1444.23(13.7)$ & $1395.03(31.9)$ \\
\hline
\end{tabular}


Table 4 - Analysis of variance (ANOVA) for compressive strength values

\begin{tabular}{cccccc}
\hline Factor & $\begin{array}{c}\text { Degree of } \\
\text { freedom }(\mathrm{df})\end{array}$ & $\begin{array}{c}\text { Mean squares } \\
(\mathrm{MS})\end{array}$ & $\mathrm{F}$ & $\begin{array}{c}\text { P-value } \\
(95 \%)\end{array}$ & Significance* \\
\hline A: RA & 2 & 0.19 & 0.61 & 0.560977 & No \\
B: Fiber & 1 & 689.25 & 2243.19 & 0.000000 & Yes \\
Interaction AB & 2 & 2.80 & 9.10 & 0.003937 & Yes \\
Error & 12 & 0.31 & & & \\
* Significant at 5\% probability (P-value <0.05) & & & &
\end{tabular}

Table 5. Values of the parameters of the constitutive model used in the numerical simulations

\begin{tabular}{|c|c|}
\hline Property & Value \\
\hline Poisson's ratio & $v=0.15$ \\
\hline Initial Young's modulus & $E=12000.0 \mathrm{~N} / \mathrm{mm}^{2}$ \\
\hline Trilinear tension-softening diagram & $\begin{array}{c}f_{c t}=1.4 \mathrm{MPa} ; G_{f}^{I} 2.5 \mathrm{~N} / \mathrm{mm} ; \xi_{1}=0.01 ; \alpha_{1}=0.60 ; \\
\xi_{2}=0.10 ; \alpha_{2}=0.90\end{array}$ \\
\hline Parameters modeling the in-plane-shear & $\tau_{t, p}^{c r}=0.5 \mathrm{~N} / \mathrm{mm}^{2} ; G_{f, s}=0.1 \mathrm{~N} / \mathrm{mm} ; \beta=0.5$ \\
\hline Parameters modeling the out-plane-shear & $G_{f}^{\prime \prime \prime}=1.0 \mathrm{~N} / \mathrm{mm}$ \\
\hline $\begin{array}{l}\text { Parameter defining the mode I fracture } \\
\text { energy available for the new crack (X) }\end{array}$ & $p_{2}=2$ \\
\hline Crack bandwidth & $\mathrm{lb}=$ Square root of the area of the integration point \\
\hline Threshold angle & $\alpha_{\text {rh }}=30^{\circ}$ \\
\hline $\begin{array}{l}\text { Maximum number of cracks per } \\
\text { integration point }\end{array}$ & 2 \\
\hline
\end{tabular}
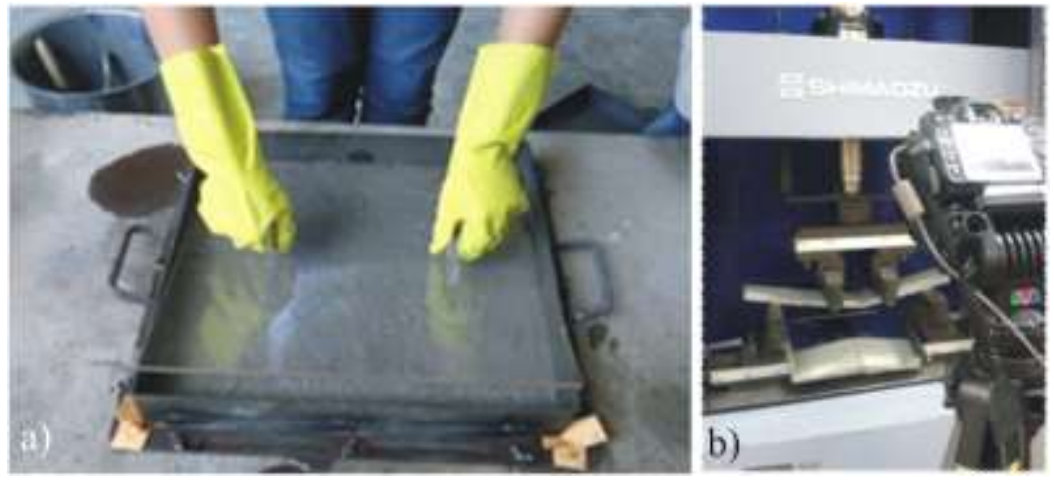

Figure 1. Flexural test: a) Production of the composite; b) test setup 

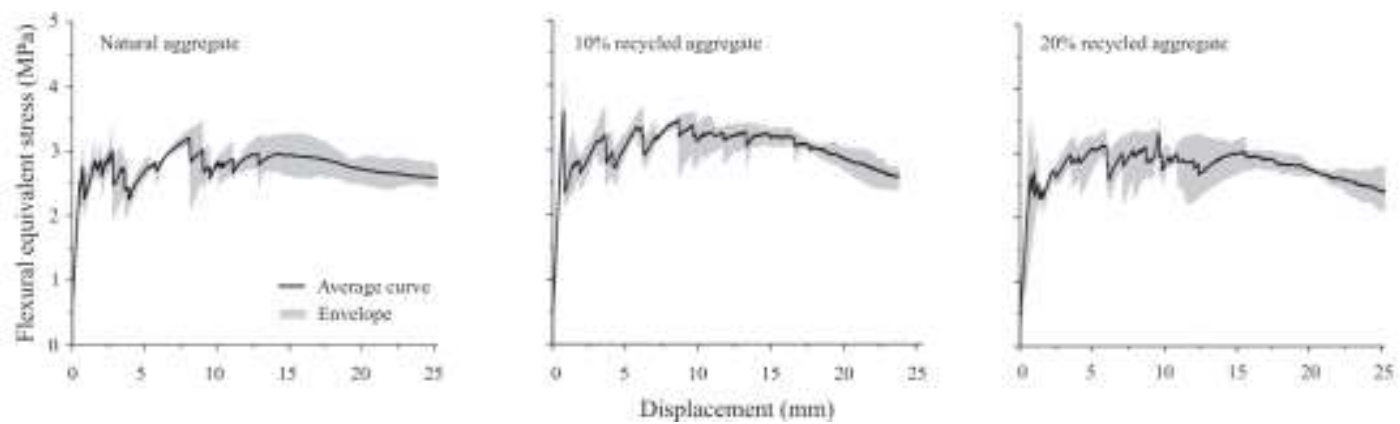

Figure 2. Effect of RA on the flexural behavior of composites

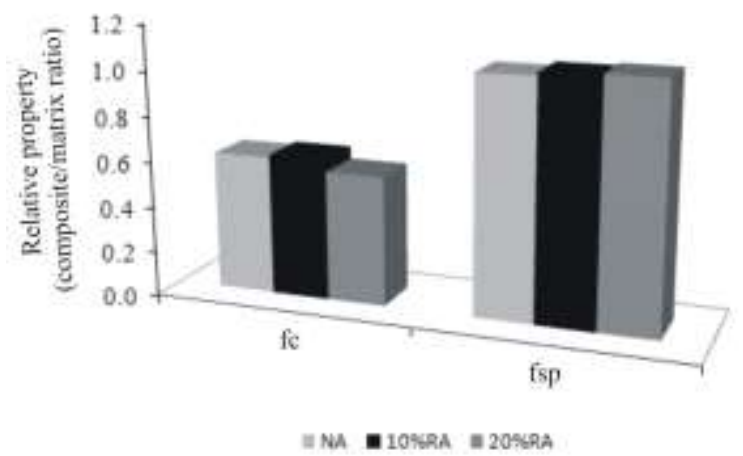

Figure 3. Effect of sisal fiber on mechanical properties of natural and recycled matrices

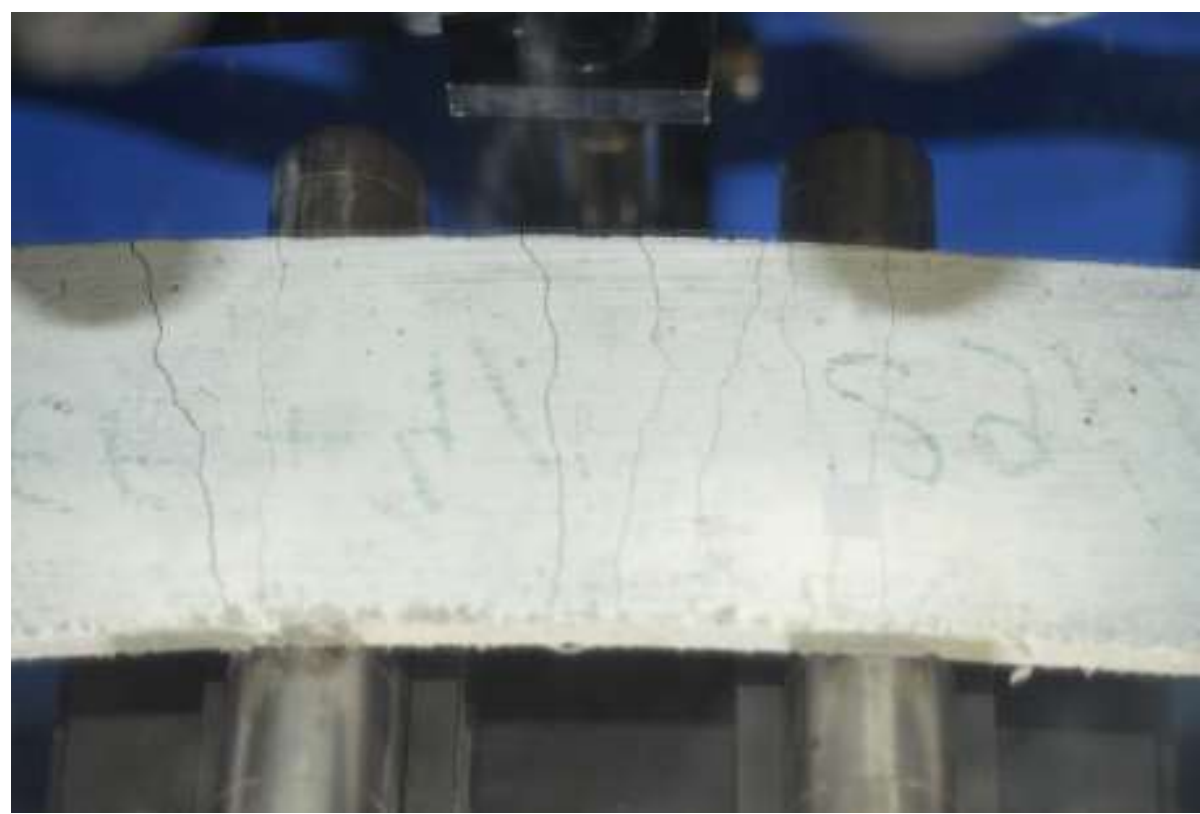

Figure 4. Experimental cracking pattern of composite plate 


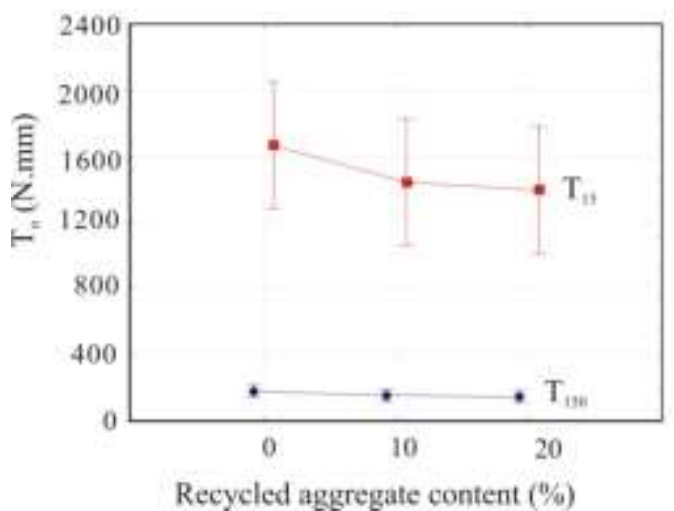

Figure 5. Effect of recycled aggregate on flexural toughness

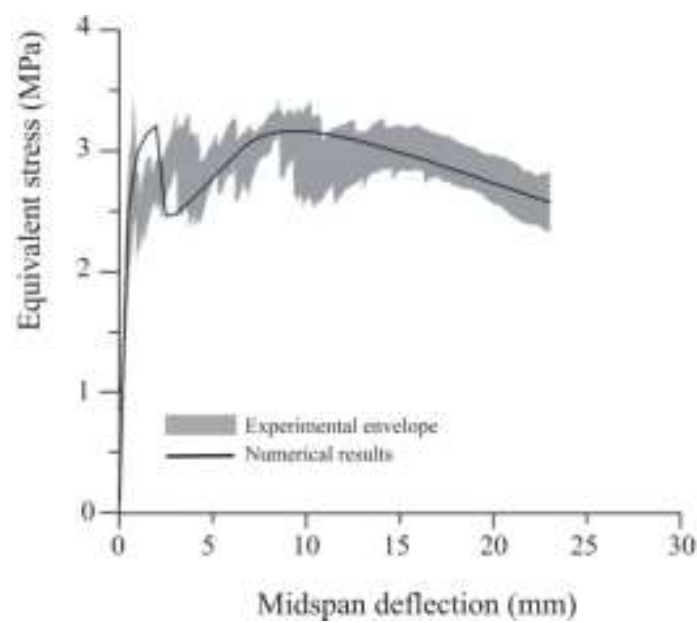

Figure 6. Numerical modeling of composite plate

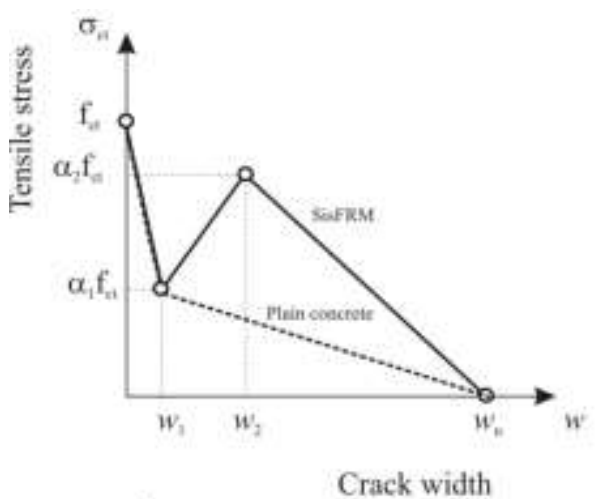

a)

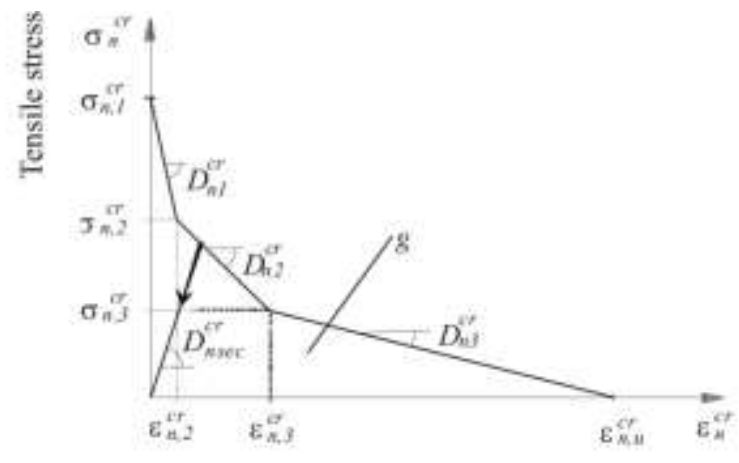

b)

Figure 7. Diagrams for modelling of SisFRCC: a) Tensile stress-crack width diagram b) Fracture mode I $\left(\sigma_{n, 1}^{c r}=f_{c t}, \sigma_{n, 2}^{c r}=\alpha_{1} \sigma_{n, 1}^{c r}, \sigma_{n, 3}^{c r}=\alpha_{2} f_{c t}, \varepsilon_{n, 2}^{c r}=\xi_{1} \varepsilon_{n, u}^{c r}, \varepsilon_{n, 3}^{c r}=\xi_{2} \varepsilon_{n, u}^{c r}\right)$ 

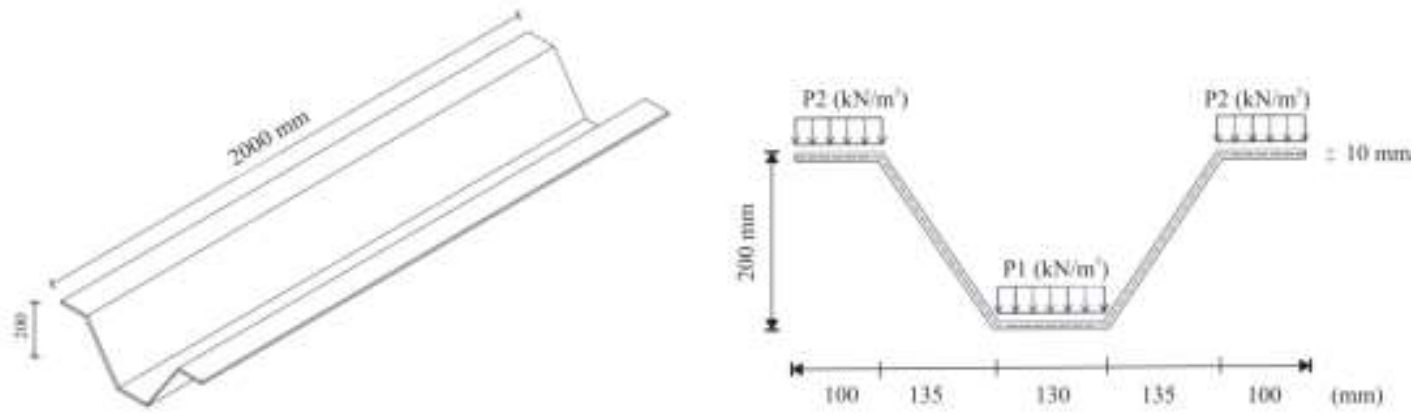

Figure 8. Constructive element modeled: a) geometry proposed; b) loading

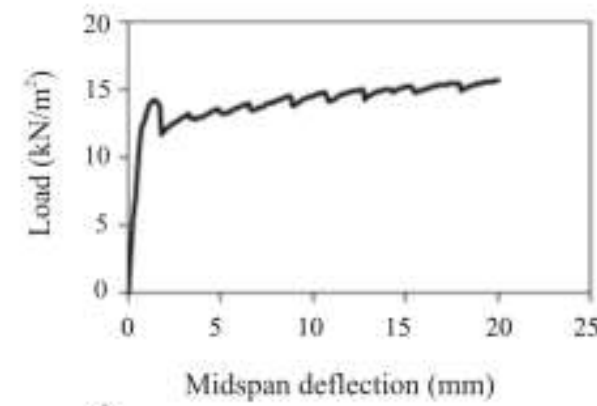

a)

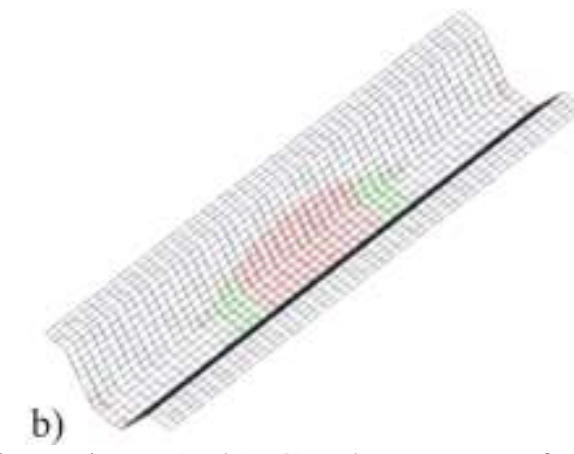

b)

Figure 9. Load case 1: a) $\mathrm{p}-\mathrm{u}_{3}\left(\mathrm{p}, \mathrm{kN} / \mathrm{m}^{2}\right)$ in point $\mathrm{P} 1$; b) Crack patterns for the top layers at a deflection at $1.5 \mathrm{~mm}$;

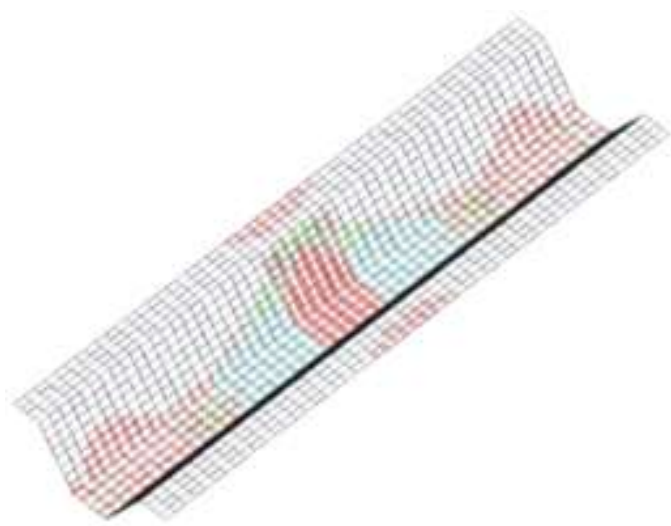

a)



b)

Figure 10. Crack patterns of load case 1 at a deflection at $10 \mathrm{~mm}$ : a) top layers; b) bottom layers 


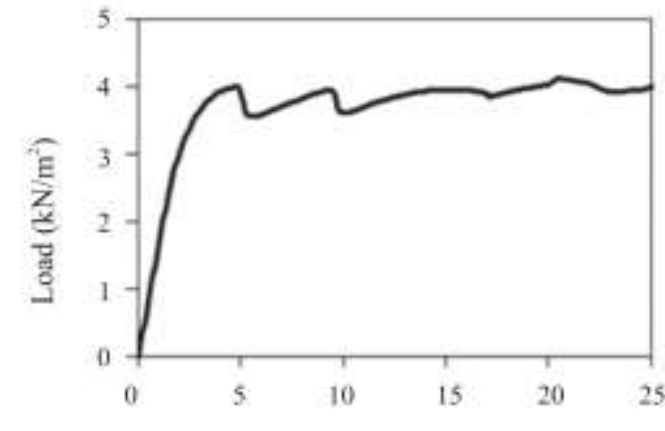

a) b)



Figure 11. Load case 2: a) Uniformly distributed load ( $\mathrm{p}, \mathrm{kN} / \mathrm{m}^{2}$ ) versus vertical deflection $\left(u_{3}\right)$; b) Crack pattern in the top layer at a deflection of $5 \mathrm{~mm}$ 